\title{
INVESTIGATIONS OF MENINGOCOCCAL INFECTION. III. THE BACTERICIDAL ACTION OF NORMAL AND IMMUNE SERA FOR THE MENINGOCOCCUS ${ }^{1}$
}

\author{
By LEWIS THOMAS ${ }^{2}$ aNd JOHN H. DINGLE \\ (From the Thorndike Memorial Laboratory, Second and Fourth Medical Services (Harvard), \\ Boston City Hospital, and the Departments of Medicine and of Bacteriology and \\ Immunology, Harvard Medical School, Boston)
}

(Received for publication October 6, 1942)

The immunological mechanisms which enable the infected host to kill the meningococcus have constituted an unsettled problem since the earliest studies of this organism. It has usually been assumed that bacteriolysis plays an important role, especially since normal sera possess bactericidal properties for many strains of meningococci, but many investigators have encountered difficulties in the demonstration of bactericidal antibodies in immune sera. For example, Murray (1) stated that immune horse sera failed to exhibit bacteriolytic antibodies, and suggested that " the precipitin reaction interfered with the result by fixing the available alexine." Gordon (2) found antimeningococcal sera " remarkably deficient in bacteriolysin." Matsunami and Kolmer (3) reported that immune sera possessed bactericidal properties of low order, and found that higher dilutions of serum were sometimes more bactericidal than lower ones. Silverthorne and his associates (4), in recent years, have applied the bactericidal test to the study of patients and immunized animals, employing fresh citrated blood for most of the tests, and have reported consistent increases in the bactericidal power of blood from convalescent patients as well as from immunized animals; these reports do not, however, deal with actual titrations of immune serum in the presence of neutral complement.

Because of the frequent finding of strong bactericidal activity in fresh, undiluted normal serum, ${ }^{3}$ the bactericidal test assumes greater significance as a quantitative measure of antibody when bactericidal property can be demonstrated in considerable dilutions of antiserum. The present com-

1 This study was aided in part by a grant from the William W. Wellington Memorial Research Fund.

2 Fellow of the Frederick Tilney Memorial Fund.

${ }^{8}$ Hereinafter the term "fresh serum" will indicate fresh undiluted serum. munication is concerned with the conditions under which such a test is possible, and also with the effect of excessive amounts of specific antibody upon the bactericidal mechanism in vitro and in vivo. The application of the bactericidal test to the study of antibody formation in human beings has been described in the preceding paper (5).

\section{MATERIAL AND METHODS}

Bactericidal test. The method was similar to that employed in a previous study of the influenza bacillus (6). The various strains of meningococci used in the experiments were maintained in storage on carbon-dioxide ice, each strain being suspended in milk and distributed in a large number of sealed pyrex tubes. During each week, the strains were maintained by daily transfers on blood agar or serum-dextrose agar slants; at the end of the week, these strains were discarded and a new lot removed from storage. For each test, the organisms were grown for 6 hours on serum-dextrose agar slants, or, in some of the experiments, on casein-hydrolysate starch-agar medium. Suspensions of this growth were made in broth, and 10 -fold serial dilutions were prepared in broth. The turbidity of the original suspension was adjusted by means of a photoelectric turbidometer so that $0.1 \mathrm{ml}$. of the $10^{-6}$ dilution contained approximately 100 organisms. Plate counts were also carried out, using the $10^{-6}$ and $10^{-7}$ dilutions, as an additional check on the number of organisms.

The materials used in the tests were mixed in the following proportions : complement, $0.25 \mathrm{ml}$.; heat-inactivated antiserum, $0.05 \mathrm{ml}$; dilutions of organisms from $10^{-1}$ to $10^{-6}, 0.05 \mathrm{ml}$. In tests of the bactericidal action of fresh serum or defibrinated blood, volumes of $0.25 \mathrm{ml}$. were mixed with $0.05 \mathrm{ml}$. of organisms. The mixtures were made in small pyrex tubes which were then sealed and placed in an automatic rotator in an incubator. Twenty hours was adopted as the time of incubation in all the tests, after which the tubes were opened, the contents thoroughly mixed, and approximately $0.05 \mathrm{ml}$. from each tube planted on the surface of a blood agar plate. The presence of any growth on the plate was taken to indicate the absence of bactericidal property in the serum tested for the number of organisms inoculated.

Complement. Fresh normal serum or defibrinated blood was obtained from healthy adults with no history of pre- 
vious meningococcal infection or exposure. Fresh rabbit, guinea pig, and horse sera were also employed as complement. The sera were always used within a few hours after bleeding, and were kept on ice during the interim.

Antisera. The following antisera were used in the experiments: (1) several samples of commercial Group I rabbit antiserum, refined and concentrated,4 (2) Group I horse antiserum, unconcentrated, 5 (3) convalescent serum from a number of patients with Group I meningococcal meningitis, and (4) several lots of serum prepared in this laboratory by the immunization of rabbits and guinea pigs with single strains of Group I meningococci, recently isolated from the cerebrospinal fluid of patients. The method of immunization consisted of daily injections, intravenously in rabbits and intraperitoneally in guinea pigs, of $1.0 \mathrm{ml}$. of a turbid saline suspension of living organisms, in 5-day courses, with rest intervals of 4 to 5 days between each course. The animals were bled 1 week or more after the last immunizing dose. The antisera were inactivated by heating at $56^{\circ} \mathrm{C}$. for 30 minutes.

Titrations of hemolytic complement. These were performed in some of the experiments. The following method was used: Varying quantities of the serum to be tested were diluted in normal saline so as to make a final volume of $0.5 \mathrm{ml}$. To this were added 2 units of amboceptor contained in $0.5 \mathrm{ml}$. of saline, and $0.5 \mathrm{ml}$. of a 2 per cent suspension of washed sheep red corpuscles. The mixtures were incubated at $37.5^{\circ} \mathrm{C}$. for 30 minutes. The last tube in which complete hemolysis occurred was selected as the endpoint. For convenience, the titer of complement has been expressed in units which represent the reciprocal of the final dilution of fresh serum.

\section{RESULTS}

\section{The bactericidal action of normal and immune sera}

\section{The bactericidal property of normal serum for meningococci}

Different strains of meningococci exhibited wide differences in their susceptibility to the bactericidal action of the same sample of fresh normal human serum. These differences could not be correlated with the virulence of the organisms for mice, nor with the serological grouping of the strains. A detailed account of this observation has been presented in the first paper of this series (7).

Some variation was also encountered in the bactericidal potency of fresh serum from different normal individuals. This variation was not, however, as striking as the differences in susceptibility between the strains themselves. The sera of 4 in-

4 Supplied by The Lederle Laboratories, Inc.

5 Supplied by Dr. Leo Rane, of the Massachusetts State Antitoxin Laboratory. fants between the ages of 6 months and 1 year were somewhat less bactericidal than the sera of adults, but even these infant sera possessed strong bactericidal action for 1 virulent strain of Group I meningococcus (Strain No. 30). Fresh serum from normal rabbits had approximately the same degree of bactericidal action for meningococci as adult human serum. Fresh guinea pig serum, as previously shown by Silverthorne (8), produced bacteriolysis of Group I meningococci with regularity, but not of Group II organisms.

The bactericidal action of normal serum appeared to be dependent upon the presence of complement, since it disappeared in every instance when the serum was heated at $56^{\circ} \mathrm{C}$. for $30 \mathrm{~min}$ utes. This was demonstrated with 3 different strains, all of which were susceptible to the bactericidal action of fresh human, rabbit, and guinea pig serum.

In general, it was possible to divide Group I meningococci into two main classes, based upon the bactericidal action of normal human and rabbit serum, namely, resistant and susceptible strains. The line of division between these two groups was not sharply definable, since occasional normal sera were encountered which failed to kill the generally susceptible strains, while others

TABLE I

Comparison of the bactericidal action of fresh serum and defibrinated blood of 7 normal individuals with the resistant strain of Group I meningococcus (No. 21)

\begin{tabular}{|c|c|c|c|c|c|c|c|}
\hline \multirow{2}{*}{ Person } & \multirow{2}{*}{ Test } & \multicolumn{6}{|c|}{ Dilution of organisms * } \\
\hline & & $10^{-1}$ & $10^{-2}$ & $10^{-3}$ & $10^{-4}$ & $10^{-8}$ & $10^{-6}$ \\
\hline $\mathrm{T}$ & $\begin{array}{l}\text { Serum } \\
\text { Blood }\end{array}$ & + & + & $\stackrel{+}{0}$ & $\begin{array}{l}+ \\
0\end{array}$ & $\begin{array}{l}+ \\
0\end{array}$ & $\stackrel{+}{0}$ \\
\hline G. & $\begin{array}{l}\text { Serum } \\
\text { Blood }\end{array}$ & + & $\begin{array}{l}+ \\
+\end{array}$ & $\stackrel{+}{0}$ & $\stackrel{+}{0}$ & $\stackrel{+}{0}$ & $\begin{array}{l}+ \\
0\end{array}$ \\
\hline B. & $\begin{array}{l}\text { Serum } \\
\text { Blood }\end{array}$ & $\stackrel{+}{0}$ & $\stackrel{+}{0}$ & $\stackrel{+}{0}$ & $\stackrel{+}{0}$ & $\begin{array}{l}\mathbf{0} \\
\mathbf{0}\end{array}$ & $\begin{array}{l}\mathbf{0} \\
\mathbf{0}\end{array}$ \\
\hline Ms. & $\begin{array}{l}\text { Serum } \\
\text { Blood }\end{array}$ & + & $\stackrel{+}{+}$ & + & + & + & + \\
\hline Ro. & $\begin{array}{l}\text { Serum } \\
\text { Blood }\end{array}$ & + & + & + & + & + & + \\
\hline Hs. & $\begin{array}{l}\text { Serum } \\
\text { Blood }\end{array}$ & + & + & + & + & + & + \\
\hline St. & $\begin{array}{l}\text { Serum } \\
\text { Blood }\end{array}$ & + & + & $\stackrel{+}{+}$ & + & $\stackrel{+}{+}$ & + \\
\hline
\end{tabular}

$* 0.05 \mathrm{ml}$. of $10^{-}$dilution $=50$ organisms.

$+=$ Growth. $0=$ No growth 
caused bacteriolysis of the generally resistant strains. Despite this flexibility, however, this rough classification was found to be useful, since the two groups presented important differences in the bactericidal tests with immune sera.

Two representative Group I strains were selected for the experiments to follow, designated as strain No. 2 (usually susceptible) and strain No. 21 (usually resistant).

\section{The bactericidal property of normal defibrinated blood}

In some normal individuals, the bactericidal action of defibrinated blood was the same as that of fresh serum. In others, strong bactericidal activity for the resistant strain was present in defibrinated blood and absent in serum. These differences between individuals are illustrated in Table $\mathrm{I}$.

\section{The effect of immune serum in the bactericidal test with the resistant strain (No. 21)}

The bactericidal action of heat-inactivated rabbit antiserum for the resistant strain was tested in the presence of human complement, rabbit com-

TABLE II

Bactericidal tests with the resistant strain (No. 21), using rabbit antiserum in presence of different types of complement

\begin{tabular}{|c|c|c|c|c|c|c|c|}
\hline \multirow{2}{*}{ Complement } & \multirow{2}{*}{$\underset{\text { dilution } \dagger}{\text { Antiserum }}$} & \multicolumn{6}{|c|}{ Dilution of organisms * } \\
\hline & & $10^{-1}$ & $10^{-2}$ & $10^{-3}$ & $10^{-4}$ & $10^{-6}$ & $10^{-6}$ \\
\hline $\begin{array}{l}\text { Rabbit } \\
\text { serum } \\
\text { diluted } \\
1-2\end{array}$ & $\begin{array}{l}1-60 \\
1-600 \\
1-6000 \\
1-30,000 \\
1-60,000 \\
\text { None }\end{array}$ & $\begin{array}{l}+ \\
+ \\
+ \\
+ \\
+ \\
+\end{array}$ & $\begin{array}{l}+ \\
+ \\
+ \\
+ \\
+ \\
+\end{array}$ & $\begin{array}{l}+ \\
+ \\
0 \\
+ \\
+ \\
+\end{array}$ & $\begin{array}{l}+ \\
+ \\
0 \\
0 \\
0 \\
+\end{array}$ & $\begin{array}{l}+ \\
+ \\
0 \\
0 \\
0 \\
+\end{array}$ & $\begin{array}{l}+ \\
0 \\
0 \\
0 \\
0 \\
+\end{array}$ \\
\hline $\begin{array}{l}\text { Human } \\
\text { serum } \\
\text { diluted } \\
1-2\end{array}$ & $\begin{array}{l}1-6 \\
1-60 \\
1-600 \\
1-6000 \\
1-60,000 \\
1-300,000 \\
1-600,000 \\
\text { None }\end{array}$ & $\begin{array}{l}+ \\
+ \\
+ \\
+ \\
+ \\
+ \\
+\end{array}$ & $\begin{array}{l}+ \\
+ \\
+ \\
+ \\
+ \\
+ \\
+\end{array}$ & $\begin{array}{l}+ \\
+ \\
+ \\
+ \\
+ \\
+ \\
+\end{array}$ & $\begin{array}{l}+ \\
+ \\
+ \\
+ \\
+ \\
+ \\
+ \\
+\end{array}$ & $\begin{array}{l}+ \\
+ \\
+ \\
+ \\
+ \\
+ \\
+ \\
+\end{array}$ & $\begin{array}{l}+ \\
+ \\
+ \\
+ \\
+ \\
+ \\
+ \\
+\end{array}$ \\
\hline $\begin{array}{l}\text { Human } \\
\text { defi- } \\
\text { brinated } \\
\text { blood }\end{array}$ & $\begin{array}{l}1-600 \\
1-3000 \\
1-6000 \\
1-30,000 \\
1-60,000 \\
\text { None }\end{array}$ & $\begin{array}{l}+ \\
+ \\
+ \\
+ \\
+ \\
+\end{array}$ & $\begin{array}{l}+ \\
0 \\
0 \\
0 \\
+ \\
+\end{array}$ & $\begin{array}{l}+ \\
0 \\
0 \\
0 \\
+ \\
+\end{array}$ & $\begin{array}{l}+ \\
0 \\
0 \\
0 \\
0 \\
+\end{array}$ & $\begin{array}{l}0 \\
0 \\
0 \\
0 \\
0 \\
+\end{array}$ & $\begin{array}{l}0 \\
0 \\
0 \\
0 \\
0 \\
0\end{array}$ \\
\hline
\end{tabular}

$0.05 \mathrm{ml}$. of $10^{-7}$ dilution $=50$ organisms. $+=$ Growth.

$\dagger$ Expressed as final dilution. plement, and normal human defibrinated blood. The following results were obtained:

(1) With rabbit serum as complement, strong bactericidal action was produced by rabbit antiserum in dilutions as high as $1: 60,000$. A conspicuous prozone was present (Table II).

(2) With human serum as complement, no bactericidal action was demonstrable in any dilution of rabbit antiserum (Table II).

(3) With normal human defibrinated blood as complement, however, bactericidal action was produced by high dilutions of rabbit antiserum, again with a prozone (Table II).

(4) Bactericidal antibody could be demonstrated in human convalescent serum in the presence of human defibrinated blood, but not when

TABLE III

Bactericidal tests with the susceptible (No. 2) and resistant (No. 21) strains of Group I meningococcus with human complement lacking bactericidal action for strain No. 2

\begin{tabular}{|c|c|c|c|c|c|c|c|}
\hline \multirow{2}{*}{ Strain } & \multirow{2}{*}{$\begin{array}{c}\text { Dilution } \\
\text { of } \\
\text { rabbit } \\
\text { antiserum }\end{array}$} & \multicolumn{6}{|c|}{ Dilution of organisms* } \\
\hline & & $10^{-1}$ & $10^{-2}$ & $10^{-3}$ & $10^{-4}$ & $10^{-6}$ & $10^{-6}$ \\
\hline No. 2 & $\begin{array}{l}1-60 \\
1-600 \\
1-6000 \\
1-60,000 \\
\text { None }\end{array}$ & $\begin{array}{l}+ \\
+ \\
+ \\
+\end{array}$ & $\begin{array}{l}+ \\
+ \\
+ \\
+ \\
+\end{array}$ & $\begin{array}{l}+ \\
0 \\
0 \\
+ \\
+\end{array}$ & $\begin{array}{l}+ \\
0 \\
0 \\
0 \\
+\end{array}$ & $\begin{array}{l}+ \\
0 \\
0 \\
0 \\
+\end{array}$ & $\begin{array}{l}+ \\
0 \\
0 \\
0 \\
+\end{array}$ \\
\hline No. 21 & $\begin{array}{l}1-60 \\
1-600 \\
1-6000 \\
1-60,000 \\
\text { None }\end{array}$ & $\begin{array}{l}+ \\
+ \\
+ \\
+ \\
+\end{array}$ & $\begin{array}{l}+ \\
+ \\
+ \\
+ \\
+\end{array}$ & $\begin{array}{l}+ \\
+ \\
+ \\
+ \\
+\end{array}$ & $\begin{array}{l}+ \\
+ \\
+ \\
+ \\
+\end{array}$ & $\begin{array}{l}+ \\
+ \\
+ \\
+ \\
+\end{array}$ & $\begin{array}{l}+ \\
+ \\
+ \\
+ \\
+\end{array}$ \\
\hline
\end{tabular}

$* 0.05 \mathrm{ml}$. of $10^{-6}$ dilution $=50$ organisms.

$t=$ Growth. $\quad 0=$ No growth.

human serum was employed as complement. These results have been presented in detail in the preceding paper (5).

The effect of immune serum in the bactericidal test with the susceptible strain (No. 2)

It has already been mentioned that an occasional normal human serum was encountered which lacked bactericidal action against the susceptible strain. When the fresh serum of such an individual was used as complement, strong bactericidal action was demonstrated in dilutions of rabbit antiserum. In a simultaneous test, the same complement was ineffective against the resistant strain (Table III). 
Bactericidal antibody was also demonstrated in human convalescent serum by this method (5).

\section{The bactericidal action of fresh immune serum}

The fresh sera of a number of rabbits were tested for bactericidal action with the resistant (No. 21) and susceptible (No. 2) strains, before and after. active immunization with Group I meningococci. A similar experiment was performed with a guinea pig. The results were as follows :

(1) Light immunization against the resistant strain resulted in the development of good bactericidal action for this organism in the fresh serum of 2 rabbits. One animal received a single intravenous injection of organisms and was bled 9 days later (Rabbit 39). The second rabbit was given 7 injections and was bled one week after the last dose (Rabbit 12) (Table IV).

TABLE IV

Bactericidal action of fresh immune rabbit sera for the resistant strain (No. 21) following immunization with this strain

\begin{tabular}{|c|c|c|c|c|c|c|c|}
\hline \multirow{2}{*}{$\underset{\text { number }}{\text { Rabbit }}$} & \multirow{2}{*}{$\begin{array}{l}\text { Number } \\
\text { of injec- } \\
\text { tions of } \\
\text { antigen }\end{array}$} & \multicolumn{6}{|c|}{ Dilution of organisms $†$} \\
\hline & & $10^{-1}$ & $10^{-2}$ & $10^{-3}$ & $10^{-4}$ & $10^{-5}$ & $10^{-6}$ \\
\hline $\begin{array}{c}39 \\
12 \\
7 \\
3 \\
\text { Normal }\end{array}$ & $\begin{array}{r}1 \\
7 \\
19 \\
32 \\
0\end{array}$ & $\begin{array}{l}+ \\
+ \\
+ \\
+ \\
+\end{array}$ & $\begin{array}{l}+ \\
+ \\
+ \\
+ \\
+\end{array}$ & $\begin{array}{l}0 \\
0 \\
+ \\
+ \\
+\end{array}$ & $\begin{array}{l}0 \\
0 \\
+ \\
+ \\
+\end{array}$ & $\begin{array}{l}0 \\
0 \\
+ \\
+ \\
+\end{array}$ & $\begin{array}{l}0 \\
0 \\
+ \\
+ \\
+\end{array}$ \\
\hline
\end{tabular}

* Sera diluted 1-2.

$\dagger 0.05 \mathrm{ml}$. of $10^{-6}$ dilution $=50$ organisms.

$+=$ Growth. $\quad 0=$ No growth.

(2) Heavy immunization against the resistant strain, consisting of 19 injections in one rabbit (Rabbit 7) and 32 injections in another (Rabbit 3 ), resulted in no demonstrable bactericidal action in the fresh serum (Table IV).

(3) Heavy immunization against the susceptible strain, amounting to at least 20 injections of organisms, resulted in the loss of bactericidal action in the fresh serum of 3 rabbits (Table V). Furthermore, bactericidal action for this strain was also lacking in the fresh sera of the 2 rabbits which were heavily immunized against the resistant strain.

(4) The sera of these 5 heavily immunized rabbits, although devoid of bactericidal action when undiluted or diluted $1: 2$, contained abundant bac-
TABLE $v$

The loss of bactericidal action in fresh serum for the susceptible strain (No. 2) following prolonged immunisation

\begin{tabular}{l|c|c|c|c|c|c|c}
\hline \hline \multirow{2}{*}{ Animal } & $\begin{array}{c}\text { Number of } \\
\text { injections } \\
\text { of } \\
\text { antigen }\end{array}$ & \multicolumn{5}{|c}{ Dilution of organisms* } \\
\cline { 2 - 6 } Rabbit & $10^{-1}$ & $10^{-2}$ & $10^{-3}$ & $10^{-4}$ & $10^{-6}$ & $10^{-6}$ \\
\hline \multirow{3}{*}{ Rabbit } & 0 & + & + & 0 & 0 & 0 & 0 \\
& 30 & + & + & + & + & + & + \\
\hline \multirow{3}{*}{ Rabbit } & 0 & + & + & + & 0 & 0 & 0 \\
& 12 & + & + & + & + & 0 & 0 \\
& 32 & + & + & + & + & + & + \\
\hline Guinea pig & 0 & + & + & + & 0 & 0 & 0 \\
& 12 & + & + & + & 0 & 0 & 0 \\
& 32 & + & + & + & + & + & + \\
\hline
\end{tabular}

$* 0.05 \mathrm{ml}$. of $10^{-6}$ dilution $=50$ organisms.

$+=$ Growth.

$0=$ No growth.

tericidal antibody. This could be demonstrated by inactivating and diluting each serum in the presence of normal rabbit complement, and testing with the resistant strain. In each instance, a prozone was present with dilutions as high as 1:60, but strong bactericidal action was exerted by dilutions of $1: 600$ and $1: 6,000$. An illustrative titration is shown in Table VI.

No bactericidal action was present in any dilution of the fresh immune sera in normal saline, nor in normal rabbit serum which had been inactivated. The reason for this may be that dilutions of fresh serum which were within the range of complement activity were also within the range of the prozone. It may be added that titrations

TABLE VI

The bactericidal action of fresh immune rabbit serum for the resistant strain (No. 21) compared with dilutions of the same serum in the presence of normal rabbit complement

\begin{tabular}{|c|c|c|c|c|c|c|c|}
\hline \multirow{2}{*}{ Test } & \multirow{2}{*}{$\begin{array}{l}\text { Dilution of } \\
\text { antiserum }\end{array}$} & \multicolumn{6}{|c|}{ Dilution of organisms * } \\
\hline & & $10^{-1}$ & $10^{-2}$ & $10^{-3}$ & $10^{-4}$ & $10^{-6}$ & $10^{-\rightarrow}$ \\
\hline $\begin{array}{l}\text { Fresh anti- } \\
\text { serum }\end{array}$ & Undiluted & + & + & + & + & + & + \\
\hline $\begin{array}{l}\text { Normal rab- } \\
\text { bit comple- } \\
\text { ment di- } \\
\text { luted } 1-2\end{array}$ & $\begin{array}{l}1-60 \\
1-600 \\
1-3000 \\
1-6000\end{array}$ & $\begin{array}{l}+ \\
+ \\
+ \\
+\end{array}$ & $\begin{array}{l}+ \\
+ \\
+ \\
+\end{array}$ & $\begin{array}{l}+ \\
0 \\
+ \\
+\end{array}$ & $\begin{array}{l}+ \\
0 \\
0 \\
0\end{array}$ & $\begin{array}{l}+ \\
0 \\
0 \\
0\end{array}$ & $\begin{array}{l}+ \\
0 \\
0 \\
0\end{array}$ \\
\hline \multicolumn{2}{|c|}{$\begin{array}{l}\text { Normal rabbit comple- } \\
\text { ment alone }\end{array}$} & + & + & + & + & + & + \\
\hline
\end{tabular}

* $0.05 \mathrm{ml}$. of $10^{-6}$ dilution $=50$ organisms.

$t=$ Growth. $0=$ No growth. 
of hemolytic complement in these immune sera revealed no difference from the complement titers of normal rabbit sera.

(5) A guinea pig, which was immunized with the resistant strain for a total of 32 injections, showed an almost complete loss in the bactericidal action of his fresh serum for this strain (Table V). As in the case of the immune rabbit sera, the addition of $1: 6,000$ dilutions of this animal's immune serum, inactivated, to normal rabbit complement, resulted in strong bactericidal action.

The fresh serum and defibrinated blood of 2 horses, which had undergone immunization with living Group I meningococci during the preceding year, were tested for bactericidal action against the resistant and susceptible strains. The organisms survived in dilutions of $10^{-4}$ in the serum and blood of both horses. When the sera were inactivated and tested in the presence of fresh normal horse serum with the resistant strain, no bactericidal action occurred. However, when normal horse defibrinated blood was employed instead of serum as complement, killing of this strain took place with antiserum in dilutions of $1: 60,000$. A prozone was observed.

During the course of immunization, one of the immunized horses developed bacteremia, due to a

TABLE VII

Comparison of the inhibitory effect of 2 rabbit antisera upon the bactericidal action of normal rabbit serum

\begin{tabular}{|c|c|c|c|c|c|c|c|}
\hline \multirow{2}{*}{$\begin{array}{l}\text { Immune } \\
\text { serum }\end{array}$} & \multirow{2}{*}{ Dilution } & \multicolumn{6}{|c|}{ Dilution of organisms * } \\
\hline & & $10^{-1}$ & $10 \rightarrow$ & $10^{-3}$ & $10^{-4}$ & $10^{-\rightarrow}$ & $10^{-6}$ \\
\hline Rabbit A & $\begin{array}{l}1-12 \\
1-24 \\
1-48 \\
1-96 \\
1-192 \\
1-384 \\
1-768 \\
1-1536\end{array}$ & $\begin{array}{l}+ \\
+ \\
+ \\
+ \\
+ \\
+ \\
+ \\
+\end{array}$ & $\begin{array}{l}+ \\
+ \\
+ \\
+ \\
+ \\
+ \\
+ \\
+\end{array}$ & $\begin{array}{l}+ \\
+ \\
+ \\
+ \\
0 \\
0 \\
0 \\
0\end{array}$ & $\begin{array}{l}+ \\
+ \\
+ \\
+ \\
+ \\
+ \\
+ \\
0\end{array}$ & $\begin{array}{l}+ \\
+ \\
+ \\
0 \\
0 \\
0 \\
0 \\
0\end{array}$ & $\begin{array}{l}+ \\
+ \\
0 \\
0 \\
0 \\
0 \\
0 \\
0\end{array}$ \\
\hline Rabbit B & $\begin{array}{l}1-12 \\
1-24 \\
1-48 \\
1-96 \\
1-192 \\
1-384 \\
1-768 \\
1-1536\end{array}$ & $\begin{array}{l}+ \\
+ \\
+ \\
+ \\
+ \\
+ \\
+ \\
+\end{array}$ & $\begin{array}{l}+ \\
+ \\
+ \\
+ \\
+ \\
+ \\
+ \\
+\end{array}$ & $\begin{array}{l}+ \\
+ \\
+ \\
+ \\
+ \\
+ \\
0 \\
+\end{array}$ & $\begin{array}{l}+ \\
+ \\
+ \\
+ \\
+ \\
+ \\
+ \\
+\end{array}$ & $\begin{array}{l}+ \\
+ \\
+ \\
+ \\
+ \\
+ \\
0 \\
0\end{array}$ & $\begin{array}{l}+ \\
+ \\
+ \\
+ \\
+ \\
+ \\
+ \\
0\end{array}$ \\
\hline \multicolumn{2}{|c|}{$\begin{array}{l}\text { Control-Comple- } \\
\text { ment alone }\end{array}$} & + & + & $\mathbf{0}$ & $\mathbf{0}$ & $\mathbf{0}$ & 0 \\
\hline
\end{tabular}

$0.05 \mathrm{ml}$. of $10^{-6}$ dilution $=50$ organisms.

$+=$ Growth. strain of Group I meningococcus. The fresh serum of this animal was completely lacking in bactericidal property for this strain.

Observations which are considered to be analogous to these results with animal sera were made in 3 patients during the course of Group I meningococcal infection (5). The fresh serum of each patient was tested for bactericidal action against his own strain of meningococcus during the acute and convalescent stages of the disease. Each patient was found to have good bactericidal action during the acute stage, which disappeared almost completely during convalescence. At the latter time, each of the patients had developed specific agglutinins and complement-fixing antibodies. Furthermore, bactericidal antibodies were demonstrable when the convalescent sera were diluted and added to normal human defibrinated blood.

\section{The inhibitory effect of immune sera upon the bactericidal action of normal sera, for Group I meningococci}

The foregoing experiments have indicated that antisera for Group I meningococci contain demonstrable bactericidal antibodies, but these are readily masked by a prozone which may occur in the fresh undiluted antiserum as well as in dilutions of inactivated antiserum plus normal complement. The loss of natural bactericidal action in fresh serum, following immunization, suggested that this prozone was due to actual inhibition by antibody excess rather than simply the passive failure of bactericidal antibody to function. It was then of interest to determine whether similar inhibition could be induced by the addition of immune serum to fresh normal serum.

When rabbit antiserum, inactivated by heating, was added to fresh normal rabbit serum, the bactericidal action of the latter for the susceptible strain disappeared. The degree of inhibitory effect appeared to be related to the antibody titer of the antiserum, as is shown in Table VII. Antiserum $A$, with a complement fixation titer of $1: 64$, caused complete inhibition when diluted $1: 24$ and incomplete inhibition in higher dilutions as far as $1: 384$. Antiserum B, with a complement fixation titer of $1: 2048$, produced complete inhibition in a dilution of $1: 384$, and incomplete inhibition in dilutions as high as $1: 1536$. 
A similar inhibitory effect was exerted by rabbit antiserum upon the natural bactericidal action of fresh normal human and guinea pig sera. Several samples of horse antiserum also produced inhibition. Convalescent sera from 4 patients with Group I meningococcal meningitis caused inhibition of the bactericidal action of normal human serum, as was shown in the preceding paper (5). No inhibition of natural bactericidal action was observed with numerous normal serum controls, nor with horse antisera for pneumococcus Type II, Friedländer's bacillus, and $H$. influenzae, nor with the convalescent serum of 6 patients with pneumococcal pneumonia.

TABLE VIII

The inhibitory effect of rabbit antiserum in varying dilutions of fresh normal serum

\begin{tabular}{c|c|c|c|c|c|c|c}
\hline \hline \multirow{2}{*}{$\begin{array}{c}\text { Complement } \\
\text { dilution }\end{array}$} & $\begin{array}{c}\text { Antiserum } \\
\text { dilution }\end{array}$ & \multicolumn{5}{|c}{ Dilution of organisms* } \\
\cline { 2 - 6 } & & $10^{-1}$ & $10^{-2}$ & $10^{-3}$ & $10^{-4}$ & $10^{-6}$ & $10^{-6}$ \\
\hline \multirow{5}{*}{ Undiluted } & $1-6$ & + & + & 0 & 0 & 0 & 0 \\
& $1-60$ & 0 & 0 & 0 & 0 & 0 & 0 \\
& $1-600$ & 0 & 0 & 0 & 0 & 0 & 0 \\
& None & 0 & 0 & 0 & 0 & 0 & 0 \\
\hline \multirow{5}{*}{$1-2$} & $1-6$ & + & + & + & + & + & + \\
& $1-60$ & + & 0 & 0 & 0 & 0 & 0 \\
& $1-600$ & + & + & 0 & 0 & 0 & 0 \\
& None & + & + & 0 & 0 & 0 & 0 \\
\hline \multirow{5}{*}{$1-4$} & $1-6$ & + & + & + & + & + & + \\
& $1-60$ & + & + & 0 & 0 & 0 & 0 \\
& $1-600$ & + & + & 0 & 0 & 0 & 0 \\
& None & + & + & + & + & 0 & 0 \\
& & &
\end{tabular}

$* 0.05 \mathrm{ml}$. of $10^{-6}$ dilution $=50$ organisms.

$+=$ Growth. $\quad 0=$ No growth.

No inhibitory effect of antiserum could be demonstrated in some samples of fresh normal serum which were possessed of a very high degree of natural bactericidal action. It was found that the inhibition was more striking with $1: 2$ dilutions of normal serum than when the latter was used undiluted. In higher dilutions of normal serum, the natural bactericidal property diminished rather abruptly, and the addition of dilutions of antiserum produced some enhancement of bactericidal action while the zone of inhibition became recognizable as a prozone (Table VIII).

The rabbit antisera used in the foregoing tests had no anti-complementary effect upon fresh normal rabbit or guinea pig serum. An experiment was conducted to determine whether the in- hibitory effect of antiserum was caused by fixation of complement in the normal serum through the interaction of specific antibody with antigen. Tubes containing fresh normal rabbit serum, and fresh normal serum plus inactivated rabbit antiserum, were inoculated with the $10^{-5}$ broth dilution of the susceptible strain. The tubes were then incubated in a candle-jar for 2 hours, after which plate counts were made with $0.1 \mathrm{ml}$. from each tube. Titrations of hemolytic complement were performed before and after incubation. It was found that complete killing of the organisms had taken place in the fresh normal serum, while the plate count from the tube containing normal serum plus antiserum showed 260 colonies in 0.05 $\mathrm{ml}$. The titer of hemolytic complement remained approximately the same in both tubes, indicating that the survival of organisms in the presence of specific antiserum was not caused by the fixation of complement.

The inhibitory effect of rabbit antiserum was sharply reduced by absorption with Group I organisms. This was shown with 3 different samples of antiserum, which were inactivated by heating and mixed with an equal volume of a turbid suspension of washed meningococci. The mixtures were incubated for 2 hours at $37.5^{\circ} \mathrm{C}$. and kept in an icebox for 18 hours. Three samples of normal rabbit serum were similarly treated. Following absorption, each serum was filtered through a Seitz pad and tested for its effect upon the bactericidal action of fresh normal rabbit serum. Simultaneous tests were made with 1:2 dilutions of the original, unabsorbed

TABLE IX

The reduction in the inhibitory action of immune rabbit serum following absorption with Group I meningococci

\begin{tabular}{|c|c|c|c|c|c|c|c|}
\hline \multirow{2}{*}{$\begin{array}{c}\text { Comple- } \\
\text { ment }\end{array}$} & \multirow{2}{*}{$\begin{array}{l}\text { Rabbit } \\
\text { serum }\end{array}$} & \multicolumn{6}{|c|}{ Dilution of organisms * } \\
\hline & & $10^{-1}$ & $10^{-2}$ & $10^{-3}$ & $10^{-4}$ & $10^{-5}$ & $10^{-1}$ \\
\hline \multirow{7}{*}{$\begin{array}{l}\text { Fresh, } \\
\text { normal } \\
\text { rabbit } \\
\text { serum, } \\
\text { diluted } \\
1-2\end{array}$} & Normal before & 0 & $\mathbf{0}$ & 0 & 0 & 0 & 0 \\
\hline & $\begin{array}{l}\text { absorption } \\
\text { Normal after }\end{array}$ & 0 & 0 & 0 & 0 & 0 & 0 \\
\hline & absorption & & & & & & \\
\hline & Immune before & + & + & + & + & + & + \\
\hline & $\begin{array}{l}\text { absorption } \\
\text { Immune after }\end{array}$ & + & + & + & 0 & 0 & $\mathbf{0}$ \\
\hline & $\begin{array}{c}\text { absorption } \\
\text { Complement }\end{array}$ & + & 0 & 0 & 0 & 0 & \\
\hline & $\begin{array}{l}\text { alone } \\
\text { alinent }\end{array}$ & & & & & & \\
\hline
\end{tabular}

$0.05 \mathrm{ml}$. of $10^{-6}$ dilution $=50$ organisms. $+=$ Growth. 
sera. The results are shown in Table IX. The normal rabbit serum produced no effect on the bactericidal action of fresh normal serum, either before or after absorption. The immune serum, before absorption, caused inhibition of bactericidal action for all dilutions of organisms, while following absorption, the inhibition extended only as far as the $10^{-3}$ dilution.

\section{The effect of intravenous injections of anti- serum upon the bactericidal action of fresh serum}

\section{Method}

Normal rabbits, weighing between 2000 and 3000 grams, were injected intravenously with varying amounts of Group I antimeningococcus serum. Three varieties of antiserum were employed: (1) horse antiserum, unconcentrated; (2) commercial rabbit antiserum, refined and concentrated; and (3) rabbit antiserum prepared in this laboratory. In addition, some rabbits were injected with a preparation of concentrated normal human globulin. The animals were bled immediately before each injection and again after 30 minutes. Serum from each bleeding was obtained by centrifugation as soon as clotting occurred, and was kept on ice. Bactericidal tests and complement titrations were performed simultaneously, within a few hours of the time of bleeding. The sera were diluted 1:2 in saline for all the bactericidal tests.

Two normal human adults were injected intravenously with commercial rabbit antiserum, refined and concentrated, in $25 \mathrm{ml}$. and $40 \mathrm{ml}$. quantities. Bactericidal tests with defibrinated blood as well as serum, and complement titrations, were performed before and 30 minutes after the injection of antiserum.

\section{Results}

The results of the experiments with rabbits are summarized in Table $\mathrm{X}$.

The injection of small amounts of horse antiserum $(0.1 \mathrm{ml}$. and $0.5 \mathrm{ml}$.) was followed by the appearance of strong bactericidal action in the fresh serum for the resistant strain (No. 21). When larger doses were injected, this effect was no longer seen, and when $10 \mathrm{ml}$. were injected, the bactericidal property for the susceptible strain
(No. 2) disappeared (Experiments 1 to 4 ). When a single rabbit was given successive injections of increasing amounts of antiserum at halfhourly intervals, bactericidal action appeared after the $0.5 \mathrm{ml}$. dose, diminished after $1.0 \mathrm{ml}$., and disappeared after $2.5 \mathrm{ml}$. (Experiment 5). No diminution in hemolytic complement occurred following any dose of horse antiserum.

The concentrated rabbit antiserum was found to be highly anticomplementary when injected intravenously into rabbits. Following doses of 0.5 $\mathrm{ml}$. or greater, no hemolytic complement could be detected by the method employed. In some animals, this effect persisted for as long as $\mathbf{2 4}$ hours after injection. This antiserum was also found to be anticomplementary in vitro, in dilutions as high as $1: 1024$. The effect on the bactericidal action of fresh serum was similar to that of horse antiserum, i.e., small amounts of antiserum produced enhancement of bactericidal property for the resistant strain, but doses of $2.5 \mathrm{ml}$. or greater caused the loss of bactericidal action for the susceptible strain (No. 2) (Experiments 6 to 12). It should be noted that an increase in killing occurred, despite an accompanying diminution in titratable complement, with doses of $0.5 \mathrm{ml}$. and $1.0 \mathrm{ml}$.

The effect of an anticomplementary substance lacking specific antibody was determined by injecting varying amounts of concentrated human globulin, which had approximately the same in vitro anticomplementary effect as the concentrated rabbit antiserum. The injection of $1.0 \mathrm{ml}$. resulted in the disappearance of detectable complement for 18 hours and also caused the loss of bactericidal action for the susceptible strain (No 2). The same effect was produced by an injection of $5.0 \mathrm{ml}$., while doses of less than $1.0 \mathrm{ml}$. had no significant effect upon either complement or bactericidal property (Experiments 13 to 16 ).

Several experiments were performed with rabbit antiserum prepared in this laboratory, which, like the horse antiserum, had no anticomplementary action. Definite results were not obtained, and unfortunately the experiments could not be extended because of an inadequate supply of this serum. No effect upon bactericidal action was produced by the injections except that in 2 animals there was some diminution following injections of $5 \mathrm{ml}$. and $10 \mathrm{ml}$. amounts (Experiments 
TABLE $\mathrm{X}$

The bactericidal action and complement titer of rabbit serum before and after the injection of antiserum and normal human globulin

\begin{tabular}{|c|c|c|c|c|c|c|c|c|c|c|c|}
\hline \multirow{2}{*}{$\begin{array}{l}\text { Material } \\
\text { injected }\end{array}$} & \multirow{2}{*}{$\begin{array}{c}\text { Experiment } \\
\text { number }\end{array}$} & \multirow{2}{*}{ Strain } & \multirow{2}{*}{$\begin{array}{c}\begin{array}{c}\text { Dose } \\
\text { of } \\
\text { antiserum } \\
(m l .)\end{array} \\
\text { (m) }\end{array}$} & \multirow{2}{*}{ Time } & \multicolumn{6}{|c|}{ Dilution of organisms } & \multirow{2}{*}{$\underset{(u n i t s)^{*}}{\text { Complement }}$} \\
\hline & & & & & $10^{-1}$ & $10^{-2}$ & $10^{-3}$ & $10^{-4}$ & $10^{-6}$ & $10^{-6}$ & \\
\hline \multirow{5}{*}{$\begin{array}{l}\text { Horse } \\
\text { antiserum }\end{array}$} & 1 & 21 & 0.1 & $\begin{array}{l}\text { Before } \\
\text { After }\end{array}$ & + & $\stackrel{+}{+}$ & $\stackrel{+}{0}$ & $\stackrel{+}{0}$ & $\stackrel{+}{0}$ & $\stackrel{+}{0}$ & $\begin{array}{l}15 \\
15\end{array}$ \\
\hline & 2 & 21 & 0.5 & $\begin{array}{l}\text { Before } \\
\text { After }\end{array}$ & + & + & $\stackrel{+}{0}$ & $\begin{array}{l}+ \\
0\end{array}$ & $\stackrel{+}{0}$ & $\begin{array}{l}+ \\
0\end{array}$ & $\begin{array}{l}25 \\
25\end{array}$ \\
\hline & 3 & 21 & 1.0 & $\begin{array}{l}\text { Before } \\
\text { After }\end{array}$ & + & + & + & + & + & + & $\begin{array}{l}25 \\
25\end{array}$ \\
\hline & 4 & 2 & 10.0 & $\begin{array}{l}\text { Before } \\
\text { After }\end{array}$ & + & + & + & $\begin{array}{l}0 \\
+\end{array}$ & $\begin{array}{l}0 \\
+\end{array}$ & $\begin{array}{l}0 \\
+\end{array}$ & $\begin{array}{l}15 \\
15\end{array}$ \\
\hline & 5 & 21 & $\begin{array}{l}\text { None } \\
0.1 \\
0.5 \\
1.0 \\
2.5 \\
5.0\end{array}$ & $\begin{array}{l}\text { Before } \\
\text { After } \\
\text { After } \\
\text { After } \\
\text { After } \\
\text { After }\end{array}$ & $\begin{array}{l}+ \\
+ \\
+ \\
+ \\
+ \\
+\end{array}$ & $\begin{array}{l}+ \\
+ \\
0 \\
+ \\
+ \\
+\end{array}$ & $\begin{array}{l}+ \\
0 \\
0 \\
+ \\
+ \\
+\end{array}$ & $\begin{array}{l}+ \\
0 \\
0 \\
+ \\
+ \\
+\end{array}$ & $\begin{array}{l}+ \\
0 \\
0 \\
0 \\
+ \\
+\end{array}$ & $\begin{array}{l}+ \\
0 \\
0 \\
0 \\
+ \\
+\end{array}$ & $\begin{array}{l}5 \\
5 \\
5 \\
5 \\
5 \\
5\end{array}$ \\
\hline \multirow{7}{*}{$\begin{array}{l}\text { Concen- } \\
\text { trated } \\
\text { rabbit } \\
\text { antiserum }\end{array}$} & 6 & 21 & 0.1 & $\begin{array}{l}\text { Before } \\
\text { After }\end{array}$ & + & + & $\begin{array}{l}+ \\
0\end{array}$ & $\begin{array}{l}+ \\
0\end{array}$ & $\stackrel{+}{0}$ & $\stackrel{+}{0}$ & $\begin{array}{l}25 \\
25\end{array}$ \\
\hline & 7 & 21 & 0.5 & $\begin{array}{l}\text { Before } \\
\text { After }\end{array}$ & + & + & $\begin{array}{l}+ \\
0\end{array}$ & $\stackrel{+}{0}$ & $\stackrel{+}{0}$ & $\stackrel{+}{0}$ & $\begin{array}{r}5 \\
<3\end{array}$ \\
\hline & 8 & 21 & 1.0 & $\begin{array}{l}\text { Before } \\
\text { After }\end{array}$ & + & + & $\stackrel{+}{0}$ & $\stackrel{+}{0}$ & $\stackrel{+}{0}$ & $\begin{array}{l}0 \\
0\end{array}$ & $\begin{array}{l}15 \\
<3\end{array}$ \\
\hline & 9 & 21 & 2.5 & $\begin{array}{l}\text { Before } \\
\text { After }\end{array}$ & + & + & + & + & + & + & $<3^{7.5}$ \\
\hline & 10 & 21 & 5.0 & $\begin{array}{l}\text { Before } \\
\text { After }\end{array}$ & + & + & + & + & + & + & $\begin{array}{r}5 \\
<3\end{array}$ \\
\hline & 11 & 2 & 2.5 & $\begin{array}{l}\text { Before } \\
\text { After }\end{array}$ & + & + & $\stackrel{+}{+}$ & $\begin{array}{l}0 \\
+\end{array}$ & $\begin{array}{l}0 \\
+\end{array}$ & $\begin{array}{l}0 \\
+\end{array}$ & $<3^{7.5}$ \\
\hline & 12 & 2 & 5.0 & $\begin{array}{l}\text { Before } \\
\text { After }\end{array}$ & + & + & $\begin{array}{l}0 \\
+\end{array}$ & $\begin{array}{l}0 \\
+\end{array}$ & $\begin{array}{l}0 \\
+\end{array}$ & $\begin{array}{l}0 \\
+\end{array}$ & $\begin{array}{r}5 \\
<3\end{array}$ \\
\hline \multirow{4}{*}{$\begin{array}{l}\text { Concentrated } \\
\text { human } \\
\text { globulin }\end{array}$} & 13 & 2 & 0.1 & $\begin{array}{l}\text { Before } \\
\text { After }\end{array}$ & + & + & $\begin{array}{l}0 \\
+\end{array}$ & $\begin{array}{l}0 \\
0\end{array}$ & $\begin{array}{l}0 \\
0\end{array}$ & $\begin{array}{l}0 \\
0\end{array}$ & $\begin{array}{l}15 \\
15\end{array}$ \\
\hline & 14 & 2 & 0.5 & $\begin{array}{l}\text { Before } \\
\text { After }\end{array}$ & + & + & $\begin{array}{l}0 \\
+\end{array}$ & $\begin{array}{l}\mathbf{0} \\
\mathbf{0}\end{array}$ & $\begin{array}{l}0 \\
0\end{array}$ & $\begin{array}{l}\mathbf{0} \\
\mathbf{0}\end{array}$ & $\begin{array}{l}7.5 \\
5\end{array}$ \\
\hline & 15 & 2 & 1.0 & $\begin{array}{l}\text { Before } \\
\text { After }\end{array}$ & + & + & + & $\begin{array}{l}0 \\
+\end{array}$ & $\begin{array}{l}0 \\
+\end{array}$ & $\begin{array}{l}0 \\
+\end{array}$ & $<3^{7.5}$ \\
\hline & 16 & 2 & 5.0 & $\begin{array}{l}\text { Before } \\
\text { After }\end{array}$ & + & $\stackrel{+}{+}$ & $\begin{array}{l}0 \\
+\end{array}$ & $\begin{array}{l}0 \\
+\end{array}$ & $\begin{array}{l}0 \\
+\end{array}$ & $\begin{array}{l}0 \\
+\end{array}$ & $<3^{7.5}$ \\
\hline \multirow{5}{*}{$\begin{array}{l}\text { Monovalent } \\
\text { rabbit anti- } \\
\text { serum un- } \\
\text { concentrated }\end{array}$} & 17 & 21 & 5.0 & $\begin{array}{l}\text { Before } \\
\text { After }\end{array}$ & + & + & + & + & $\begin{array}{l}0 \\
+\end{array}$ & $\begin{array}{l}0 \\
+\end{array}$ & $\begin{array}{l}15 \\
15\end{array}$ \\
\hline & 18 & 21 & 10.0 & $\begin{array}{l}\text { Before } \\
\text { After }\end{array}$ & + & + & + & + & + & + & $\begin{array}{l}15 \\
15\end{array}$ \\
\hline & 19 & 21 & 20.0 & $\begin{array}{l}\text { Before } \\
\text { After }\end{array}$ & + & + & + & + & + & + & $\begin{array}{l}25 \\
25\end{array}$ \\
\hline & 20 & 2 & 5.0 & $\begin{array}{l}\text { Before } \\
\text { After }\end{array}$ & + & + & $\begin{array}{l}+ \\
0\end{array}$ & $\begin{array}{l}\mathbf{0} \\
\mathbf{0}\end{array}$ & $\begin{array}{l}\mathbf{0} \\
\mathbf{0}\end{array}$ & $\begin{array}{l}\mathbf{0} \\
\mathbf{0}\end{array}$ & $\begin{array}{l}15 \\
15\end{array}$ \\
\hline & 21 & 2 & 10.0 & $\begin{array}{l}\text { Before } \\
\text { After }\end{array}$ & + & $\begin{array}{l}0 \\
+\end{array}$ & $\begin{array}{l}0 \\
+\end{array}$ & $\begin{array}{l}\mathbf{0} \\
\mathbf{0}\end{array}$ & $\begin{array}{l}\mathbf{0} \\
\mathbf{0}\end{array}$ & $\begin{array}{l}\mathbf{0} \\
\mathbf{0}\end{array}$ & $\begin{array}{l}15 \\
15\end{array}$ \\
\hline
\end{tabular}

* The titer of complement has been expressed in units which represent the reciprocal of the highest final dilution of fresh serum producing complete hemolysis. 
17 and 21). The agglutinin titer of this serum was $1: 640$.

The results of the injection of $25 \mathrm{cc}$. of concentrated rabbit antiserum in a normal man are shown in Table XI. No effect on hemolytic complement was observed following the injection, although this was the same lot of serum which had previously been shown to be highly anticomplementary in rabbits. The bactericidal property of fresh serum and defibrinated blood for the suscep-

\section{TABLE XI}

The bactericidal action of human serum and defibrinated blood for the susceptible (No. 2) and resistant (No. 21) strains of Group I meningococci, before and after the injection of $25 \mathrm{ml}$. of concentrated rabbit antiserum

\begin{tabular}{|c|c|c|c|c|c|c|c|c|}
\hline \multirow{2}{*}{ Strain } & \multirow{2}{*}{$\begin{array}{c}\text { Material } \\
\text { tested }\end{array}$} & \multirow{2}{*}{ Time } & \multicolumn{6}{|c|}{ Dilution of organisms * } \\
\hline & & & $10^{-1}$ & $10^{-2}$ & $10^{-3}$ & $10^{-4}$ & $10^{-6}$ & $10^{-0}$ \\
\hline \multirow{2}{*}{2} & $\underset{1-2}{\text { Serum }}$ & $\begin{array}{l}\text { Before } \\
\text { After }\end{array}$ & $\begin{array}{c}0 \\
+\end{array}$ & $\begin{array}{l}0 \\
+\end{array}$ & $\begin{array}{l}0 \\
+\end{array}$ & $\begin{array}{l}0 \\
+\end{array}$ & $\begin{array}{l}\mathbf{0} \\
\mathbf{0}\end{array}$ & $\begin{array}{l}0 \\
0\end{array}$ \\
\hline & $\begin{array}{l}\text { Defibrinated } \\
\text { blood }\end{array}$ & $\begin{array}{l}\text { Before } \\
\text { After }\end{array}$ & $\begin{array}{l}0 \\
+\end{array}$ & $\begin{array}{l}0 \\
+\end{array}$ & $\begin{array}{l}\mathbf{0} \\
\mathbf{0}\end{array}$ & $\begin{array}{l}\mathbf{0} \\
\mathbf{0}\end{array}$ & $\begin{array}{l}\mathbf{0} \\
\mathbf{0}\end{array}$ & $\begin{array}{l}\mathbf{0} \\
\mathbf{0}\end{array}$ \\
\hline \multirow{2}{*}{21} & $\underset{1-2}{\text { Serum }}$ & $\begin{array}{l}\text { Before } \\
\text { After }\end{array}$ & + & + & + & + & + & + \\
\hline & $\begin{array}{l}\text { Defibrinated } \\
\text { blood }\end{array}$ & $\begin{array}{l}\text { Before } \\
\text { After }\end{array}$ & $\stackrel{+}{+}$ & + & $\stackrel{+}{0}$ & $\stackrel{+}{0}$ & $\stackrel{+}{0}$ & $\begin{array}{l}\mathbf{0} \\
\mathbf{0}\end{array}$ \\
\hline
\end{tabular}

* $0.05 \mathrm{ml}$. of $10^{-6}$ dilution $=50$ organisms.

$+=$ Growth. $\quad 0=$ No growth.

tible strain (No. 2) was definitely diminished 30 minutes after the injection. At the same time, however, a notable increase occurred in the bactericidal action of defibrinated blood for the resistant strain (No. 21). No killing of the latter strain occurred in the serum alone. Comparable results were obtained when a second individual was injected with $40 \mathrm{cc}$. of concentrated rabbit antiserum; the titer of hemolytic complement also remained the same in this subject.

\section{The effect of active and passive immunization upon the duration of induced bac- teremia in rabbits}

\section{Active immunization}

Three rabbits which had been actively immunized against Group I meningococci by 32 injections of living organisms, and 3 normal control rabbits of the same weights, were injected intravenously with $1.0 \mathrm{ml}$. of a freshly prepared turbid suspension, in saline solution, of the resistant strain (No. 21). Blood cultures were made by allowing approximately $0.5 \mathrm{ml}$. of blood to drop from an incised ear vein into $5.0 \mathrm{ml}$. of broth. Cultures were made at 30 minutes, 1 hour, 4 hours, 8 hours, 24 hours, and 48 hours after the injection of organisms.

A considerable variation in resistance to bacteremia was encountered in both groups of animals, but the immunized rabbits did not appear to be significantly different from the normal controls. In the 3 immune rabbits, the last positive cultures were obtained at 4 hours in 2 , and at 8 hours in the third. In the control rabbits, the last positive cultures were obtained at 1 hour, 8 hours, and 24 hours.

\section{Passive immunization}

Three rabbits were injected intravenously with $5.0 \mathrm{ml}$. of concentrated rabbit antiserum, known to be anti-complementary; 30 minutes later, each rabbit received $1.0 \mathrm{ml}$. of a freshly prepared turbid suspension, in saline, of the susceptible strain (No. 2). At the same time, 3 control rabbits were given the same dose of organisms. Blood cultures were made at intervals, as in the preceding experiment.

Meningococci were not cultured from the blood of any of the control animals. One of the rabbits which received antiserum had a positive culture at 8 hours, the second rabbit at 24 hours, and the third at 48 hours.

In a similar fashion, 2 rabbits were given antimeningococcal horse serum (Massachusetts No. 758), intravenously, in doses of $5 \mathrm{ml}$. and $10 \mathrm{ml}$., respectively. This antiserum was known to have no anti-complementary effect. Blood cultures taken from these and 2 control rabbits after injection of the organisms gave the following results: the 2 rabbits receiving antiserum had bacteremia at 4 hours but not at 8 hours or thereafter. Meningococci were not obtained from the blood of either of the normal control rabbits in any of the cultures.

\section{DISCUSSION}

The nature of the agent which is responsible for the bactericidal action of normal serum for the meningococcus is not clearly understood. It 
appears to resemble bactericidal antibody, as Gordon and Hoyle have shown, since it requires complement for its function, can be reactivated by the addition of complement after heating, and may be removed by absorption with specific antigen (9). However, the frequency of its appearance in presumably normal sera, the extraordinary variability in the susceptibility of different strains of the same serological group to its action, and its uniform presence in guinea pig serum for Group I organisms, might cause doubt as to its specificity as an immunological response to previous infection. This doubt is increased by certain observations made in this investigation: that fresh undiluted sera from immunized animals and convalescent human patients may be completely lacking in bactericidal action, and the addition of immune serum to normal serum results in the inhibition of the bactericidal action of the latter. An explanation for all these observations would require a more complete knowledge of the prozone phenomenon than is now available, although the prozone alone is apparently responsible in some instances. Moreover, it seems evident that the presence of bactericidal action in fresh, undiluted serum is not a reliable index of the formation of specific antibody.

On the other hand, it has been demonstrated that a very high order of bactericidal antibody is present in immune sera and can be easily detected if the proper conditions are present. These conditions are (1) the strain of meningococcus must be selected on the basis of its susceptibility to bacteriolysis. If a generally susceptible strain is employed, bactericidal antibody can be demonstrated in the presence of a non-bactericidal complementing serum. If a resistant strain is used, a difference between the effectiveness of complement from different species becomes apparent, i.e., rabbit complement is effective while human complement is not. At the same time, a second mechanism can be brought into action against the resistant strain, involving the use of defibrinated blood instead of serum alone; (2) the appropriate normal serum or defibrinated blood must be used as complement; and (3) the proper proportions of antiserum must be tested, in order to evade the masking effect of the prozone.

The inhibitory effect of antiserum upon the bactericidal actior of normal serum in vitro is a finding which is consistent with the apparent lack of bactericidal action of the sera of actively and passively immunized rabbits. There are two possible factors which may be involved in these events: (1) the prozone phenomenon, and (2) the inhibition of complement. It has been shown that either factor may produce the same end result. In the in vitro experiments with rabbit antisera, in which untreated monovalent sera were employed, and in the in vivo experiments with horse antisera, it was established that no diminution in hemolytic complement was involved in the inhibitory phenomenon. On the other hand, the results with concentrated rabbit antisera, which produced not only inhibition of bactericidal action when injected intravenously but also the persistence of bacteremia, were probably due both to the prozone phenomenon and to the anticomplementary effect of the antiserum. The reasons for this anticomplementary effect are not known. The disturbance in complement seems to have been profound, in view of the long duration of the effect. The concomitant loss of bactericidal action and hemolytic complement, which was observed following the injection of concentrated normal globulin, provides further evidence of the necessity for complement in the bactericidal mechanism.

The results of passive immunization of human subjects with concentrated rabbit antiserum are in agreement with the in vitro findings in bactericidal tests. It will be noted that the bactericidal property already present in serum for the susceptible strain was reduced, while killing of the resistant strain occurred in defibrinated blood, and no killing of the latter strain occurred in serum alone.

For clinical purposes, the observations reported here are of interest in a number of respects. First, it is evident that excessive amounts of antiserum may reduce, rather than enhance, the bactericidal property of the blood. Whether such a process can take place in the blood of a patient undergoing serum treatment remains to be determined and evaluated. Second, the loss of bactericidal action which was observed in highly immunized animals suggests that a similar process may be a factor in the development of prolonged or chronic infection with the meningococcus, such as chronic meningococcemia, and the bacteremia 
with endocarditis which is sometimes seen in immunized horses (10). Third, a considerable anticomplementary effect may be exerted in rabbits by concentrated antiserum. It has not been shown that this effect also takes place in humans, but the question is of such practical importance that it should be studied further.

\section{SUM MARY}

(1) Differences in the general susceptibility of strains of Group I meningococci were associated with differences in the behavior of these organisms in the bactericidal test with immune sera. Susceptible strains were killed, while resistant strains survived, in the presence of human complement. Resistant strains were killed in the presence of rabbit complement or human defibrinated blood.

(2) Fresh immune sera were lacking in bactericidal action for both resistant and susceptible strains. When these sera were diluted in the presence of an appropriate neutral complement, strong bactericidal antibody was demonstrable.

(3) The bactericidal action of fresh normal serum was inhibited by the addition of specific antiserum. This inhibition was not associated with detectable fixation of hemolytic complement. It is considered to be a manifestation of the prozone phenomenon.

(4) The injection of small quantities of specific antiserum in rabbits produced an increase in bactericidal property. Larger doses caused inhibition of killing. In some instances, this may have been due to the anticomplementary action of concentrated antiserum; in others, complement was not affected.

(5) The injection of concentrated antiserum in 2 human subjects resulted in the enhancement of bactericidal action in defibrinated blood, for the resistant strain, and a diminution in the bactericidal action of serum and defibrinated blood, for the susceptible strain. No detectable alteration of complement was observed.

(6) The intravenous injection in rabbits of a concentrated rabbit antimeningococcal serum resulted in the disappearance of detectable hemolytic complement for as long as 24 hours. After the intravenous injection of meningococci, bacteremia persisted for a considerably longer period in rabbits receiving antiserum than in control rabbits. Similar results were obtained using an antimeningococcal horse serum, free from any demonstrable anticomplementary effect. Two factors, operating singly or together, appear to be responsible for these results: the prozone phenomenon due to antibody excess, and anticomplementary action.

The authors are indebted to Mrs. Muriel E. Stone and Miss Marguerite Buckingham for technical assistance.

\section{BIBLIOGRAPHY}

1. Murray, E. G. D., The Meningococcus. Med. Res. Council, Spec. Rep. Series No. 124, 1929.

2. Gordon, M. H., et al., Cerebrospinal Fever. Studies in the Bacteriology, Preventive Control, and Specific Treatment of Cerebrospinal Fever Among the Military Forces, 1915-19. Med. Res. Council, Spec. Rep. Series No. 50, 1920.

3. Matsunami, T., and Kolmer, J. A., The influence of active normal serum (complement) upon meningococci. II. The bactericidal and protective value of fresh serum alone and in combination with antimeningitis serum for meningococci. J. Immunol., 1918, 3, 177.

4. Silverthorne, N., and Cameron, C., Studies on meningococcus infection. J. Pediat., 1941, 19, 618.

5. Thomas, L., Smith, H. W., and Dingle, J. H., Investigations of meningococcal infection. II. Immunological aspects. J. Clin. Invest., 1943, 22, 361.

6. Dingle, J. H., Fothergill, L. D., and Chandler, C. A., Studies on Haemophilus influenzae. III. The failure of complement of some animal species, notably the guinea pig, to activate the bactericidal function of sera of certain other species. J. Immunol., 1938, 34, 357.

7. Thomas, L., and Dingle, J. H., Investigations of meningococcal infection. I. Bacteriological aspects. J. Clin. Invest., 1943, 22, 353.

8. Silverthorne, N., Typing of meningococci: Preliminary report on survival of group I (types I-III) and type II strains of meningococci in blood of normal guinea-pigs. Canad. Pub. Health J., 1941, $32,120$.

9. Gordon, J., and Hoyle, L., The bactericidal action of serum against meningococcus, gonococcus and $\mathrm{Mi}$ crococcus catarrhalis. J. Path. and Bact., 1936, 43, 537.

10. Cohen, S. M., A study of meningococcal cultures from horses immunized against meningococci. J. Immunol., 1939, 36, 129. 